\title{
Biological control of Ralstonia solanacearum (Smith), the causal pathogen of bacterial wilt disease by using Pantoea spp
}

Kamal A. M. Abo-Elyousr ${ }^{1,2^{*}}$ a and Sabry A. Hassan ${ }^{3}$

\begin{abstract}
Background: Bacterial wilt of tomato (BWP) caused by Ralstonia solanacearum (Smith) is a very important disease. Biological control of this disease is a very important tool to protect the plant and environment from pollution of chemical control.

Results: Twenty isolates of genus, Pantoea were isolated from healthy tomato root. Out of 20 isolates, 2 strains, PHYTPO1 and PHYTPO2, showed highly antagonistic property to control the growth of $R$. solanacearum in vitro conditions. They were identified as P. agglomerans by using $16 \mathrm{~S}$ rRNA nucleotide sequence analysis. The 2 isolates were selected to study their effect (as cell suspension or culture filtrate) on the bacterial wilt under greenhouse conditions. PHYTPO1 inhibited maximum growth reduction of $R$. solanacearum and formed $2.5 \mathrm{~cm}^{2}$ of inhibition zone, followed by $1.2 \mathrm{~cm}^{2}$ in PHYTOPO2 under in vitro conditions. Treating with both isolates of P. agglomerans was significantly reduced disease severity of tomato wilt disease. The disease severity was reduced to 74.1 when treated as cell suspension, while when treated as culture filtrate, it reduced the disease severity up to 69.4 than infected control.
\end{abstract}

Conclusion: The strains of Pantoea can be used as an ecofriendly method to control of the most economic pathogen of tomato under greenhouse conditions. Further study is needed to find an appropriate formulation and approving application of these bacteria under field conditions.

Keywords: Tomato wilt, Endophyte, Biological control, Pantoea agglomerans

\section{Background}

Bacterial wilt of tomato (BWP), caused by Ralstonia solanacearum (Smith) (Yabuuchi et al. 1995) is a serious problem in many countries. This bacterium could destroy $100 \%$ of the crop production (Wang et al. 2019). BWP disease is difficult to be managed under field conditions due to its ability to survive for a long time in the soil. The long-term use of chemical products such as bactericides and fungicides induced resistance in the pathogen making it tolerant to chemical applications (Maji and Chakrabartty 2014). Generally, this disease could be managed by

\footnotetext{
*Correspondence: kaaboelyousr@agr.au.edu.eg

1 Department of Arid Land Agriculture, King Abdulaziz University,

Jeddah 80208, Saudi Arabia

Full list of author information is available at the end of the article
}

cultural practices, use of resistant cultivars and application of copper compounds, but all of these methods have a limited success (Bereika et al. 2020). Biological control can be a part of integrated disease management to control the BWP disease (Bereika et al. 2020). Entophytes or phylosphere and rizobacteria are safe for human, and very effective in reducing phytopathogenic bacteria by inducing antibiotic or secondary metabolites (AlSman et al. 2019) as well as inducing resistance in plant (Bereika et al. 2020).

Pantoea agglomerans is a very important biocontrol agent that could be used for controlling many pathogens, e.g. fungal diseases, tomato early blight caused by (Alternaria solani), rot in cotton (Pythium sp.), bacterial diseases e.g. fire blight in apple and pear caused by (Erwinia amylovora) (Laux et al. 2001), cotton blight (Bora et al. 
1993) and plant parasitic nematode, Meloidogyne javanica (Bonaterra et al. 2014). It produces single antibiotic or multiple compounds which could inhibit the bacterial growth (Laux et al. 2001). Also, it has the ability to promote the growth of plant by producing some hormones or solubilized of phosphorus as well as production of siderophores (Gutierrez Manêro et al. 2001). P. agglomerans mostly has been used to control fire blight disease in Europe or USA (Özaktan and Bora 2004). Recently, Singh et al. (2020) used $P$. agglomerans for studying its effect on the growth of $R$. solanacearum in vitro.

The present study aimed to evaluate the potential of 2 strains of $P$. agglomerans, isolated from Egypt, for inhibiting the growth of $R$. solanacearum in vitro and in vivo as well as enhancing plant growth.

\section{Methods}

\section{Isolation of bacterial bioagent}

Different soil and tomato plant samples were collected from different location of Assiut Governorate. Dilution technique methods was used to isolate Pantoea spp. from samples onto semi selective medium containing $\mathrm{KH}_{2} \mathrm{PO}_{4}$ $(0.8 \mathrm{~g}), \mathrm{D}$ - trehalose $(2.0 \mathrm{~g})$, Yeast extract $(10.0 \mathrm{mg}), \mathrm{NaCl}$ (15.0 g), 2,6- diminopurine (0.2 g), $\mathrm{MgSO}_{4} .7 \mathrm{H}_{2} \mathrm{O}(0.2 \mathrm{~g})$, $\mathrm{K}_{2} \mathrm{HPO}_{4}(0.8 \mathrm{~g})$ and agar, Bacto $(20.0 \mathrm{~g})$ and adjusted $\mathrm{pH}$ 4.9 with $1 \mathrm{NH}_{4} \mathrm{Cl}_{2}$ and then added cycloheximide $(30 \mu \mathrm{g} /$ $\mathrm{ml}$ ) (Manulis et al. 1991), after that the plates were incubated for 2 days at $28{ }^{\circ} \mathrm{C}$. Single colony was selected and transferred to NSA medium slants for further study. $R$. solanacearum PHYRS7 (MT510004), was isolated previously (Seleim et al. 2011).

\section{Effect of Pantoea sp. against $R$. solanacearum PHYRS7 in vitro conditions}

Methods of Bereika et al. (2020) was used to test the potential of the isolates to antagonize against $R$. solanacearum PHYRS7 in vitro. Bacterial isolates were cultured in NA medium for 2 days at $27{ }^{\circ} \mathrm{C}$. A $100 \mu \mathrm{l}$ $\left(10^{8} \mathrm{CFU} / \mathrm{ml}\right)$ of $48 \mathrm{~h}$-old culture of PHYRS7 have inocula load medium to make a lawn for each isolate separately with 3 replications (each contained 5 plates). After that, 3 wells of $5.0 \mathrm{~mm}$ in diameter, using sterile cork borer, were formed on the Petri plate. A $50 \mu \mathrm{l}\left(10^{8} \mathrm{CFU} / \mathrm{ml}\right)$ culture of each isolate of Pantoea sp. was inoculated into each well separately and incubated in Petri plates at $27^{\circ} \mathrm{C}$ for 2 days as well as a $50 \mu \mathrm{l}$ of culture filtrates of each isolates was inoculated in well, Culture filtrates of each isolate of Pantoea spp. were obtained after growth for 7 days at
$28{ }^{\circ} \mathrm{C}$ in NA broth. Zone of inhibition, formed by strains of Pantoea sp. was recorded.

\section{Identification of the bacterial bioagent using 16S rRNA sequence analysis}

Isolation of DNA was performed according to SaghaiMaroof et al. (1984) with some modifications. One $\mathrm{ml}$ of overnight liquid culture was placed in a $1.5 \mathrm{ml}$ disposable centrifuge tube. The cell was collected through centrifugation at $7500 \mathrm{rpm}$ for $10 \mathrm{~min}$. The supernatant was discarded, and the pellet was re-suspended in $0.2 \mathrm{ml}$ of Phosphate buffer. $10 \mu \mathrm{l}$ of lysozyme were added and incubated at $37{ }^{\circ} \mathrm{C}$ for $60 \mathrm{~min} .0 .4 \mathrm{ml}$ of CTAB extraction buffer was added, followed by $40 \mu \mathrm{l}$ of $\beta$-merca btoethanol and gently mix. The tube was placed in $60^{\circ} \mathrm{C}$ water bath for $60 \mathrm{~min}$. After cooling an equal volume of Chloroform: Isoamyl alcohol (24:1) was added and mixed. This mixture was centrifuged for 5-10 min at full speed, and the aqueous supernatant was transferred to a new tube. An equal volume of cold ethanol $100 \%$ was added then cooled at $-4^{\circ} \mathrm{C}$ for $30 \mathrm{~min}$. Then, it centrifuged for $5 \mathrm{~min}$. at $1300 \mathrm{rpm}$ to pellet the DNA. Washing was done by ethanol 70\%, followed by centrifugation for $5 \mathrm{~min}$. Finally, the pellets were kept for drying for $1 \mathrm{~h}$ at room temperature and then, dissolved in warm dist. $\mathrm{H}_{2} \mathrm{O}$. Amplification of $16 \mathrm{~S}$ rRNA gene of size 709 bp was done by using the primer set (UNI_OL5:5'GTGTAGCGGT GAA ATGCG3) and UNI_OR (5' ACGGGCGGTGTGTACAA-3) (Wattiau et al. 2001). To perform several parallel reactions, a reaction containing water, $2 \times$ master mix, primers and appropriate DNA template dilution was pre-

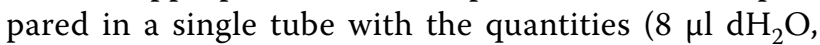
$10 \mu \mathrm{l} 2 \mathrm{X}$ Master mix, $1 \mu \mathrm{l} 20 \mu \mathrm{M}$ Forward and Reverse primers, $1.0 \mu \mathrm{l}$ Templet DNA). PCR conditions were carried out in a Lab Cycler SensoQuest, with the following parameters: template denaturation at $94{ }^{\circ} \mathrm{C}$ for $5 \mathrm{~min}$, followed by 40 cycles of denaturation at $94{ }^{\circ} \mathrm{C}$ for $1 \mathrm{~min}$, annealing at $\left(65^{\circ} \mathrm{C}\right.$ for $1406 \mathrm{f}$ and $23 \mathrm{~S}$ Primers and $57^{\circ} \mathrm{C}$ for MM5F and MM5R) for $1 \mathrm{~min}$ and extension at $72{ }^{\circ} \mathrm{C}$ for $1 \mathrm{~min}$, with a final extension at $72{ }^{\circ} \mathrm{C}$ for $10 \mathrm{~min}$ and soaked at $4{ }^{\circ} \mathrm{C}$. The obtained PCR products of each reaction $(20 \mu \mathrm{l})$ and a $100 \mathrm{bp}$ DNA Ladder were electrophoresed onto submerged agarose gel of $1 \%$ concentration containing ethidium bromide in $1 \mathrm{X}$ concentration TBE buffer ( $89 \mathrm{mM}$ Tris-borate; $2.5 \mathrm{mM}$ EDTA). The submarine gel was supplied with a direct current of $100 \mathrm{~V}$ for approximately one hour, using a power supply. The gel was then visualized and photographed, using gel documentation system. Sequence of amplified fragment was blasted in NCBI nucleotide BLAST. The phylogenetic tree was prepared by the help of Bio-informatics tool MEGA 5 software. 
Effect of $P$. agglomerans as cell suspension or culture filtrate on seed germination and seedling vigor in vitro The in vitro effect of seed pre-treatment with Pantoea was examined on tomato seed germination. Seeds (1 and 2) were soaked in each Pantoea sp. suspension $\left(1 \times 10^{8} \mathrm{cfu} / \mathrm{ml}\right)$ for $15 \mathrm{~min}$. (3 and 4) were dipped in an culture filtrate of each isolate, (5) seed soaked in PHYTR7 as negative control and (6) untreated seeds soaked in sterile distilled water served as control. Each treatment contained 3 replicates/50 seeds each. The treated seeds were placed on wet filter paper and incubated at $28{ }^{\circ} \mathrm{C}$ for one week. Germination, mean shoot length (MSR) and mean root length (MRL) were recorded. Seedling vigor index (VI) was determined, using the equation as follows (Abdul Baki and Anderson, 1973):

$$
\mathrm{VI}=(\mathrm{MSL}+\mathrm{MRL}) \cdot \text { germination } \% .
$$

\section{Effect of $P$. agglomerans as cell suspension or culture} filtrate on diseases severity under greenhouse conditions Greenhouse experiments were performed at BLINDED FOR PEER REVIEW. Seeds were sown in $20 \mathrm{~cm}$ diameter plastic pots containing a soil mixture consisting of soil: sand $(1: 1 \mathrm{w} / \mathrm{w})$ and fertilizer 1\% N.P.K. (12: 4: 6). Plants were irrigated when necessary. Twenty-eight dayold tomato seedlings cv. 'Tala F1' were inoculated by $R$. solanacearum PHYRS7 (108 cell $/ \mathrm{ml}$ ) by cutting the roots from 2 sides, with an alcohol knife inserted $4-5 \mathrm{~cm}$ into the soil and inserting $20 \mathrm{ml}$ of $R$. solanacearum PHYRS7 suspension around the base of each plant (Bereika et al. 2020). Only the pathogen was inoculated into infected control plants, which were then treated with $20 \mathrm{ml}$ sterile distilled water. After inoculation, the tomato plants were kept in a moist chamber at $25^{\circ} \mathrm{C}$ for 2 days before being transferred to the greenhouse at $25-30{ }^{\circ} \mathrm{C}$. A $20 \mathrm{ml}$ of each bioagent suspension Pantoea spp., as well as the culture filtrate of each isolate surrounding the plant bases, were added 2 days after inoculation. Four replicates were used per treatment (3 pots each). The development of bacterial wilt symptoms was observed after 21 days. The severity of the disease was measured, and the percentage of disease severity (DS percent) was calculated, using the formula of Bereika et al. (2020).

$$
\text { Disease index }(\%)=\left[\sum\left(n i \times v_{i}\right) \div(V \times N)\right] \times 100
$$

where $n i$ represents the number of plants for each disease rating, $v i$ represents the disease rating, $V$ represents the highest disease rating (5), and $N$ represents the total number of plants observed. The following scale was used to determine disease severity: $1=$ no symptoms, $2=$ one leaf wilted, $3=$ two to three leaves wilted, $4=$ four or more leaves wilted and $5=$ whole plant wilted.

At the end of experiment, 5 plants were taken to determine the fresh and dry weights of roots and shoots.

\section{Effect of $P$. agglomerans as cell suspension or culture filtrate on population of $R$. solanacearum PHYRS7 in tomato plant}

For determination of bacterial multiplication in tomato plant treated with bacterial cell or culture filtrate, one gram of the stem tissues ( $3 \mathrm{~cm}$ above the soil) of each treatment after 6 weeks from inoculation was cut and washed with tap water, surface sterilized with $3 \%$ sodium hypochloride and washed several time with sterile water. A $10 \mathrm{ml}$ of $0.1 \mathrm{M}$ potassium phosphate buffer was used to homogenize the samples in a sterile mortar and pestle ( $\mathrm{pH}$ 7.0). Stem homogenates were serially diluted in $0.1 \mathrm{M}$ potassium phosphate buffer from $10-1$ to 10-9. $200 \mu \mathrm{l}$ of each dilution was transferred to a selective medium (TTC) and distributed with a glass rod. The number of bacterial colonies was counted after $48 \mathrm{~h}$. of incubation at $27^{\circ} \mathrm{C}$.

\section{Statistical analysis}

SPSS 22.0 was used to conduct all statistical analyses. For antagonistic capability, the data were analyzed using oneway analysis of variance (ANOVA), while for the rest of the experiments, two-way analysis was used. According to Gomez and Gomez (1984), the least significant difference (LSD) test was used at P 0.05 to distinguish significant variations among the means of the treatments.

\section{Results}

\section{Antagonistic potential of the isolates}

Out of 20 isolates, 2 strains showed antagonistic potential to control the growth of $R$. solanacearum in vitro conditions. Remaining isolates showed moderate antagonistic activity against $R$. solanacearum (unpublished data). From the obtained results, the most effective 2 isolates were selected to study their culture filtrates and cell suspensions on growth of $R$. solanacearum. As results presented in Fig. 1, isolate PYTOPO2 caused the highest reduction of the pathogen growth when treated as cell suspension, followed by cell suspension of PHYTOPO1 and culture filtrate of both isolates. PHYTPO1 inhibited maximum growth of $R$. solanacearum and formed $2.5 \mathrm{~cm}^{2}$ of inhibition zone, followed by $1.2 \mathrm{~cm}^{2}$ in PHY$\mathrm{TOPO} 2$ in vitro conditions.

\section{Identification of the bioagent isolates}

Bioagent isolates were molecularly characterized by means of $16 \mathrm{~S}$ rRNA sequencing. BLAST search on the NCBI data libraries (16S ribosomal RNA sequences 


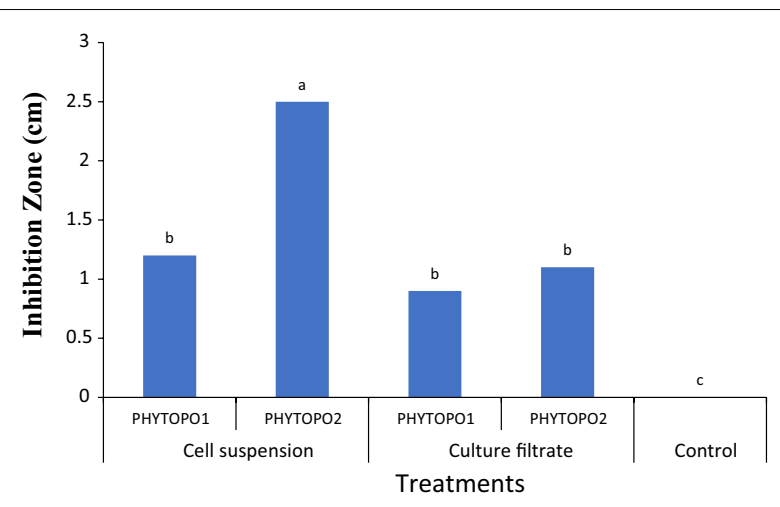

Fig. 1 Effect of two isolates of Pantoea agglomerans as cell suspension or culture filtrate on inhibition zone percentage of Ralstonia solanacearum. According to the LSD test at $p \leq 0.05$, values in the same column followed by a similar letter are not significantly different

(Bacteria and Archaea) and non-redundant nucleotide collection) for similarities of the 16S rRNA sequences showed it as the most similar to Pantoea agglomerans strain PHYTOPO1 and 2 (GenBank accession No. MT605810, MT605811) with $100 \%$ identity query coverage (Fig. 2).

\section{PGPR evaluation}

Efficiency of Pantoea agglomerans in controlling wilt disease of tomato under greenhouse conditions

The results illustrated in the Fig. 3 showed that under greenhouse conditions, treatment with both isolates of P. agglomerans PHYTPO 1 and 2 as cell suspension or culture filtrate, significantly reduced disease severity of wilt disease than the infected control (pathogen only). The disease severity was reduced by 74.1 and $70.6 \%$ when bioagents were treated as cell suspension, while when in case of the plant treated with culture filtrate, the disease severity was reduced by 69.4 and $68.2 \%$, respectively, than the infected control. Disease severity in infected control was very high (85\%), while in treated one, it ranged from 24 to $27 \%$.

\section{Effect of $P$. agglomerans as cell suspension or culture} filtrate on seed germination and seedling vigour index Both isolates and their culture filtrate treatments increased the percentage of germination. Treatment with PHYTOPO2 as cell suspension was the most effective one $(79 \%)$, it increased the percentage of seed germination up to $75.5 \%$ relative to infected control with pathogen, followed by PHYTOPO1 (Table 1). While in case of culture filtrate, it increased the germination with $55.5 \%$. In general, cell suspension increased seed germination higher than culture filtrate. The vigor index was also increased than infected control at all treatments of cell suspension and culture filtrate of both isolates, it ranged between 227.2 and 355.5 and $112.5 \%$ in infected one.

\section{Effect of $P$. agglomerans as cell suspension or culture filtrate on $R$. solanacearum population in tomato plants} The results presented in Table 2 indicated that the highest number of cell (CFU) R. solanacearum was observed in the infected control. Plant treated with PHYTOPO 1 and 2 as cell suspension or culture filtrate caused reduction of $R$. solanacearum relative to the control DW. Treatment with PHYTOPO 1 as cell suspension was the best treatment, $1.3 \times 10^{9} \mathrm{cfu} / \mathrm{g}$, followed by PHYTOPO2, $1.9 \times 10^{9} \mathrm{cfu} / \mathrm{g}$ while the lowest treatment was observed in culture filtrate of PHYTOPO1, it was $2.9 \times 10^{9} \mathrm{cfu} / \mathrm{g}$.

\section{Influence of $P$. agglomerans as cell suspension or culture filtrate on fresh and dry weight of tomato plants under greenhouse conditions}

The influence of both isolates on fresh and dry weights of roots and shoots of tomato plants was determined at the end of experiment. Fresh and dry weights of shoots and roots of plants infected with $R$. solanacearum were significantly lower than that of DW treatment. Treatments of both isolates significantly increased fresh weight of tomato shoots ( $\mathrm{g}^{-1}$ plant), arranged from 135.6 to $138.2 \mathrm{~g} /$ plant than $R$. solanacearum $60 \mathrm{~g} /$ plants (Table 3). Also, the dry weight of shoots also increased than infected control in all treatments. In case of root weight (fresh and dry), both isolates significantly increased the weight than infected control, when plants treated with cell suspension, it is better than treated with culture filtrate.

\section{Discussion}

Numerous studies have shown the role of endophytes as biocontrol agents against various plant pathogens. Endophytes are significant sources of new bioactive compounds and secondary metabolites. In the tissues of various plants, a wide variety of endophytic prokaryotic microorganisms has been reported (Zheng et al. 2018). Twenty bacterial isolates were isolated from different locations at Assiut Governorate Egypt. All isolates were tested against $R$. solanacearum, the causal pathogen of tomato wilt. The best 2 isolates, which inhibited the growth of the pathogen PHYTPR7 were selected to study their effect on the reduction of bacterial wilt of tomato and enhancement the growth of tomato plant under greenhouse condition. Both isolates were identified as $P$. agglomerans, by $16 \mathrm{~S}$ rRNA, and deposited in the GenBank under accession numbers MT605810 and MT605811 (Li et al. 2008). 


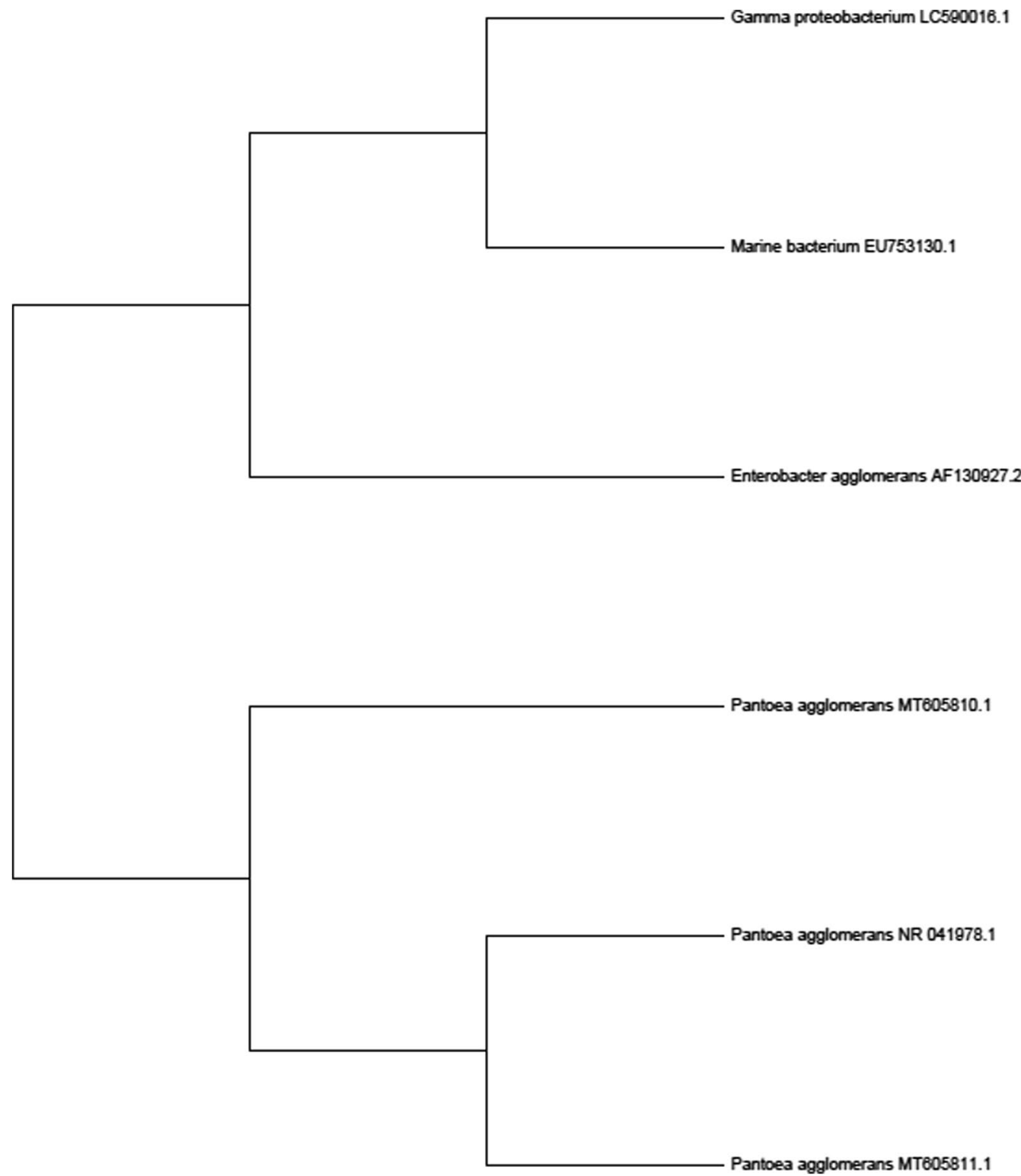

Fig. 2 Phylogenetic analysis of Pontoea isolates on ITS gene. This analysis was performed using the neighbor-joining method in BLAST pairwise alignments

In the earlier study of Johnson et al. (1993), reported that $P$. agglomerans was able to suppress diseases caused by different groups of phytopathogenic bacteria e.g. Xanthomonas albilineans (blight in sugarcane) Erwinia amylovora (fire blight of apple), and X. oryzae pv. oryzae (Zhang and Birch 1996). Wodzinski et al. (1994) stated that $P$. agglomerans could suppress the diseases by producing various antibiotics, most of these antibiotics most probably were pantocins and herbicolins as mentioned by Wright and Beer (2005).
Many researches showed that a several bacterial bioagent present in phyllosphere or rhizosphere caused enhancing the growth of the plants and suppressing the pathogens, these bioagents called plant growth-promoting bacteria (PGPR) (Miethling et al. 2000). They can enhance the growth of plants through stimulating the growth hormones and solubization of the minerals in the soil and the siderophors production (Vazquez et al. 2000).

The results reported herein showed that the disease severity was reduced by $69.4-47.1 \%$ than the control, 


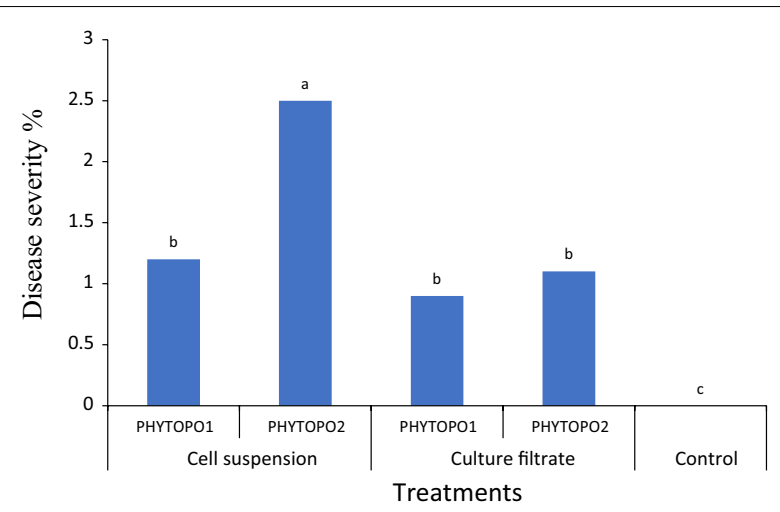

Fig. 3 Disease reduction percentage of treated tomato plants under greenhouse conditions. Columns with the same letters are not significantly different according to Fisher's protected least significant difference at $p \leq 0.05$

when both isolates were applied as cell suspension or culture filtrate, under greenhouse experiment. Using both bioagent decreased the $\mathrm{cfu} / \mathrm{g}$ in plant as well as increased biomass of the plant. These results are in agreement with those reported by Thomas and Upreti (2014), who mentioned that Pantoea ananatis can be used to control bacterial wilt of tomato plants that caused by $R$. solanacearum. They found that this endophytic bioagents had an antagonistic potentiality against phytopathogenic microorganisms, and it could be used for controlling such pathogen. In addition, endophytic bacteria, according to Podolich et al. (2007) can help protecting crops by stimulating their active form in response to environmental stress or pathogen attack, as well as improving plant growth and health.

The study in greenhouse revealed that fresh and dry weights of shoots and roots of bioagents-treated tomato plants were higher than the untreated and infected tomato plants. Several works have reported that plant treated with pathogens could increase the biomass e.g. maize (Goswami et al. 2016), tomato (Hernàndez-Suàrez et al. 2011) and potato (Bereika et al. 2020). The plant growth promotion which was observed in the PGPRtreated tomato plants could be indirectly related to the potential of the PGPR strains to reduce the severity of $R$. solanacearum on tomato plants.

\section{Conclusion}

The results concluded that the new endophytic strains of $P$. agglomerans were a potent biocontrol agent against $R$. solanacearum-the causal pathogen of wilt of tomato. It caused reduction of the disease severity and increased the crop biomass. Further research is

Table 1 In vitro effect of treatment with the bacterial bioagent as cell suspension or culture filtrate on seed germination and seedling vigour of tomato

\begin{tabular}{|c|c|c|c|c|c|}
\hline Treatments & Method of application & Germination \% & MSL (Cm) & $\operatorname{MRL}(\mathrm{Cm})$ & VI \\
\hline PHYTOPO1 & Cell suspension & $75 c$ & $1.4 \mathrm{a}$ & $3.1 \mathrm{a}$ & 337.5 \\
\hline PHYTOPO2 & Cell suspension & $79 b$ & $1.3 b$ & $3.2 \mathrm{a}$ & 355.5 \\
\hline PHYTOPO1 & Culture filtrate & $70 \mathrm{~d}$ & $1.2 \mathrm{c}$ & $2.9 \mathrm{~b}$ & 287 \\
\hline PHYTOPO2 & Culture filtrate & $71 d$ & $1.1 \mathrm{c}$ & $2.1 \mathrm{c}$ & 227.2 \\
\hline Healthy Control & Water & $85 a$ & $1.5 \mathrm{a}$ & $2.9 \mathrm{~b}$ & 374 \\
\hline Infected control & R. solanacearum & $45 \mathrm{e}$ & $0.9 d$ & $1.6 d$ & 112.5 \\
\hline
\end{tabular}

Values in the same column followed by a similar letter are not significantly different as determined by the LSD test $(P=0.05)$

Table 2 Effect of treatment with bacterial bioagents as cell suspension or culture filtrate on number of bacteria in plant under greenhouse conditions

\begin{tabular}{lll}
\hline Treatments & Method of application & $\begin{array}{c}\text { Bacterial numbers (cfu/g stem } \\
\text { tissue) after two weeks from } \\
\text { inoculation }\end{array}$ \\
\hline PHYTOPO1 & Cell suspension & $1.9 \times 10^{9 \mathrm{~cd}}$ \\
PHYTSTC7 & Cell suspension & $1.3 \times 10^{9 \mathrm{e}}$ \\
PHYTOPO1 & Culture filtrate & $2.9 \times 10^{9 \mathrm{~b}}$ \\
PHYTOPO2 & Culture filtrate & $2.2 \times 10^{9 \mathrm{c}}$ \\
Control & Water & $0.0^{\mathrm{f}}$ \\
Infected control & R. solanacearum & $4.2 \times 10^{7 \mathrm{a}}$
\end{tabular}

Values in the same column followed by a similar letter are not significantly different as determined by the LSD test $(P=0.05)$ 
Table 3 Effect of some bacterial boiagents on fresh and dry weight of shoots and root under greenhouse conditions

\begin{tabular}{|c|c|c|c|c|c|}
\hline \multirow[t]{2}{*}{ Treatments } & \multirow[t]{2}{*}{ Method of application } & \multicolumn{2}{|l|}{ Root } & \multicolumn{2}{|l|}{ Shoots } \\
\hline & & FW & DW & FW & DW \\
\hline PHYTOPO1 & Cell suspension & $14.8 \mathrm{~b}$ & $1.3 \mathrm{c}$ & $138.0 \mathrm{a}$ & $12.1 \mathrm{~b}$ \\
\hline PHYTOPO2 & Cell suspension & $16.9 a$ & $1.6 \mathrm{a}$ & $138.2 \mathrm{a}$ & $13.1 \mathrm{a}$ \\
\hline PHYTOPO1 & Culture filtrate & $13.5 c$ & $1.3 c$ & $135.6 \mathrm{~b}$ & $11.6 \mathrm{C}$ \\
\hline PHYTOPO2 & Culture filtrate & $13.6 \mathrm{C}$ & $1.5 b$ & $136.2 b$ & $13.1 \mathrm{a}$ \\
\hline Control & Water & $13.5 c$ & $1.2 \mathrm{~d}$ & $130.5 c$ & $10.1 \mathrm{~d}$ \\
\hline Infected control & R. solanacearum & $6.5 d$ & $0.8 \mathrm{e}$ & $60 d$ & $6.4 \mathrm{e}$ \\
\hline
\end{tabular}

Values in the same column followed by a similar letter are not significantly different as determined by the LSD test $(P=0.05)$

needed to find an appropriate formulation and approving application of the bacteria under field conditions.

\section{Abbreviations}

BWP: bacterial wilt of potato crop; LSD: least significant difference; IAA: indole acetic acid; MSR: mean shoot length; MRL: mean root length; VI: seedling vigor index; PHYTPO1: strain 1 of isolate P. agglomerans.

\section{Acknowledgements}

The authors extend their appreciation to Taif University for funding current work by Taif University Researchers Supporting Project number (TURSP 2020/142), Taif University, Taif, Saudi Arabia..

\section{Authors' contributions}

All authors contributed equally in the manuscript, AKAM suggested the idea of the work and contributed to data curation and their validation as well as writing original draft.SH. contributed to the formal analysis of the data., $\mathrm{SH}$ and AKAM. contributed to the reviewing and editing the manuscript. All authors read and approved the final manuscript.

\section{Funding}

The authors extend their appreciation to Taif University for funding current work by Taif University Researchers Supporting Project Number (TURSP_ 2020/142), Taif University, Taif, Saudi Arabia.

\section{Availability of data and materials}

Not applicable.

\section{Declarations}

\section{Ethics approval and consent to participate}

Not applicable. This manuscript is in accordance with the guide for authors available on the journal's website. Also, this work has not been published previously and is approved by all authors and host authorities.

\section{Consent for publication}

Not applicable.

\section{Competing interests}

No potential conflict of interest was reported by the authors.

\section{Author details}

1 Department of Arid Land Agriculture, King Abdulaziz University, Jeddah 80208, Saudi Arabia. ${ }^{2}$ Department of Plant Pathology, Faculty of Agriculture, University of Assiut, Assiut 71526, Egypt. ${ }^{3}$ Department of Biology, College of Science, Taif University, P.O. Box 11099, Taif 21944, Saudi Arabia.

Received: 24 May 2021 Accepted: 14 August 2021

Published online: 19 August 2021

\section{References}

Abdul Baki AA, Anderson JD (1973) Vigour determination in soybean seed by multiple criteria. Crop Sci 13:630-633. https://doi.org/10.2135/crops ci1973.0011183X001300060013x

Al-Sman KM, Abo-Elyousr KAM, Amal E, El-Zawahry A (2019) Efficiency of Pseudomona spp.-based formulation for controlling root rot disease of black cumin under greenhouse and field conditions. Arch Phytopathol Plant Prot 52(19-20):1313-1325. https://doi.org/10.1080/03235408.2019. 1707384

Bereika FFM, Sallam NMA, Alamri SAM, Abo-Elyousr KAM, Hashem M, Yasser SM (2020) Approving the biocontrol strategy of potato wilt caused by Ralstonia solanacearum on field scale using Enterobacter cloacae PS14 and Trichoderma asperellum T34. Egypt J Biol Pest Control 30:61. https:// doi.org/10.1186/s41938-020-00262-9

Bonaterra A, Badosa E, Rezzonico F, Duffy B, Montesinos E (2014) Phenotypic comparison of clinical and plant-beneficial strains of Pantoea agglomerans. Int Microbiol 17(2):81-90. https://doi.org/10.2436/20.1501.01.210

Bora LC, Gangopadhyay S, Chaud JN (1993) Biological control of bacterial leaf spot ( $X$. campestris pv. vignae radiatae Dye) of mung bean with phylloplane antagonists. Indian J Mycol Plant Pathol 23:162-168

Gomez KA, Gomez AA (1984) Statistical procedures for agricultural research. Wiley, New York

Goswami D, Thakker JN, Dhandhukia PC (2016) Portraying mechanics of plant growth promoting rhizobacteria (PGPR): a review. Cogent Food Agric 2:1-19. https://doi.org/10.1080/23311932.2015.1127500

Gutierrez Manêro FJ, Ramos Solano B, Probanza A, Mehouachi J, Tadeo FR, Talon M (2001) The plant growth-promoting rhizobacteria Bacillus pumilus and Bacillus licheniformis produce high amounts of physiologically active gibberellins. Physiol Plant 111:1-7. https://doi.org/10.1034/j. 1399-3054.2001.1110211.x

Hernàndez-Suàrez M, Hernàndez-Castillo FD, Gallegos-Morales G, Líra-Saldivar $\mathrm{RH}$, Rodriguez-Herrera R, Aguilar CN (2011) Biocontrol of soil fungi in tomato with microencapsulates containing Bacillus subtilis. Am J Agric Biol Sci 6(2):189-195. https://doi.org/10.3844/ajabssp.2011.189.195

Johnson KB, Stockwell VO, McLaughlin RJ, Sugar D, Loper JE, Roberts RG (1993) Effect of antagonistic bacteria on establishment of honey bee-dispersed Erwinia amylovora in pear blossoms and on fire blight control. Phytopathology 83:995-1002. https://doi.org/10.1094/Phyto-83-995

Laux P, Mao G, Zeller W (2001) Studies on the mode of action of Pantoea agglomerans 21889 against Erwinia amylovora. In: De Boer SH (ed) Plant pathogenic bacteria. Springer, Dordrecht. https://doi.org/10.1007/97894-010-0003-1_75

Li JH, Wang ET, Chen WF, Chen WX (2008) Genetic diversity and potential for promotion of plant growth detected in nodule endophytic bacteria of soybean grown in Heilongjiang province of China. Soil Biol Biochem 40(1):238-246. https://doi.org/10.1016/j.soilbio.2007.08.014

Maji S, Chakrabartty PK (2014) Bio control of bacterial wilt of tomato caused by' Ralstonia solanacearum' by isolates of plant growth promoting rhizobacteria. Aust J Crop Sci 8(2):208

Manulis S, Gafni Y, Clark E, Zutra D, Ophir Y, Barash I (1991) Identification of a plasmid DNA probe for detection of strains of Erwinia herbicola pathogenic on Gypsophila paniculata. Phytopathology 81(1):54-57. https://doi. org/10.1094/Phyto-81-54 
Miethling R, Wieland G, Backhaus H, Tebbe CC (2000) Variation of microbial rhizosphere communities in response to crop species, soil origin, and inoculation with Sinorhizobium meliloti L33. Microbial Ecol 40(1):43-56. https://doi.org/10.1007/s002480000021

Özaktan H, Bora T (2004) Biological control of fire blight in pear orchards with a formulation of Pantoea agglomerans strain Eh 24. Braz J Microbiol 35(3):224-229. https://doi.org/10.1590/S1517-83822004000200010

Podolich O, Ardanov P, Voznyuk T, Kovalchuk M, Danylchenko O, Laschevskyi V, Lyastchenko S, Kozyrovska N (2007) Endophytic bacteria from potato in vitro activated by exogenic non-pathogenic bacteria. Biopolym Cell 23:21-27. https://doi.org/10.7124/bc.000752

Saghai-Maroof MA, Soliman KM, Jorgensen RA, Allard RW (1984) Ribosomal DNAsepacer-length polymorphism in barley: mendelian inheritance, chromosomal location, and population dynamics. Proc Natl Acad Sci 81:8014-8019. https://doi.org/10.1073/pnas.81.24.8014

Seleim MAA, Saead FA, Abd-El-Moneem KMH, Abo-Elyousr KAM (2011) Biological control of bacterial wilt of tomato by plant growth promoting rhizobacteria. Plant Pathol J 10(4):146-153. https://doi.org/10.3923/ppj. 2011.146.153

Singh D, Yadav DK, Fatima F (2020) Characterization and genetic diversity of Pantoea agglomerans isolates having dual potentiality to suppress growth of Ralstonia solanacearum and plant growth promoting ability. Indian Phytopathol 73:643-653. https://doi.org/10.1007/s42360-020-00268-1

Thomas P, Upreti R (2014) Significant effects due to peptone in Kelman medium on colony characteristics and virulence of Ralstonia solanacearum in tomato. Open J Microbiol 8:87-105. https://doi.org/10.2174/ 1874285801408010095

Vazquez P, Holguín G, Puente ME, Lopez-Cortes A, Bashan Y (2000) Phosphate-solubilizing microorganisms associated with the rhizosphere of mangroves in a semiarid coastal lagoon. Biol Fertil Soils 30(5-6):460-468. https://doi.org/10.1007/s003740050024

Wang N, Wang L, Zhu K, Hou S, Chen L, Mi D (2019) Plant root exudates are involved in Bacillus cereus AR156 mediated biocontrol against Ralstonia solanacearum. Front Microbiol 10:98. https://doi.org/10.3389/fmicb.2019. 00098

Wattiau P, Renard ME, Ledent P, Debois V, Blackman G, Agathos S (2001) A PCR test to identify Bacillus subtilis and closely related species and its application to the monitoring of wastewater biotreatment. Appl Microbiol Biotechnol 56(5-6):816-819. https://doi.org/10.1007/s002530100691 Wodzinski RS, Umholtz TE, Rundle JR, Beer SV (1994) Mechanisms of inhibition of Erwiniaamylovora by E. herbicola in vitro and in vivo. J Appl Bacteriol 76(1):22-29. https://doi.org/10.1111/j.1365-2672.1994.tb04410.x

Wright SAl, Beer SV (2005) Pantoea agglomerans, a biocontrol agent and ubiquitous microorganism — friend or foe? In; Biocontrol of bacterial plant diseases, 1st symposium, pp 334-338

Yabuuchi E, Kosako Y, Yano I, Hotta H, Nishiuchi Y (1995) Transfer of two Burkholderia and an Alcaligenes species to Ralstonia genus nov:: proposal of Ralstonia pickettii (Ralston, Palleroni and Douderoff 1973) comb.nov., Ralstonia solanacearum (Smith 1896) comb. nov. and Ralstonia eutropha (Davis 1969) comb. nov. Microbiol Immunol 39:897-904

Zhang L, Birch RG (1996) Biocontrol of sugarcane leaf scald disease by an isolate of Pantoea dispersa which detoxifies albicidin phytotoxins. Lett Appl Microbiol 22:132-136. https://doi.org/10.1111/j.1472-765X.1996. tb01126.x

Zheng Y, Chiang TY, Huang C, Gong X (2018) Highly diverse endophytes in roots of Cycas bifida (Cycadaceae), an ancient but endangered gymnosperm. J Microbiol 56:337-345. https://doi.org/10.1007/ s12275-018-7438-3

\section{Publisher's Note}

Springer Nature remains neutral with regard to jurisdictional claims in published maps and institutional affiliations.

\section{Submit your manuscript to a SpringerOpen ${ }^{\odot}$ journal and benefit from:}

- Convenient online submission

- Rigorous peer review

- Open access: articles freely available online

- High visibility within the field

- Retaining the copyright to your article

Submit your next manuscript at $\boldsymbol{\nabla}$ springeropen.com 